\title{
The Implementation of Activity Based Learning (ABL) Method at Elementary School to Enhance Students' Speaking Skills
}

\author{
Emilius German $^{1 *}$, Disa Evawani Lestari² ${ }^{2}$ iD \\ ${ }^{12}$ President Univeristy, Bekasi, Indonesia \\ *Corresponding author: germanexcellent@president.ac.id
}

\begin{abstract}
Learning a foreign language can effectively take place in childhood, which is usually called the golden period. However, recent data shows the number of problems faced by elementary school students. One of the main problems identified is oral competency. This is due to a lack of teachers' knowledge of teaching methods. The primary objective of this study is to identify whether the implementation of an activity- based learning (ABL) method can improve students' speaking skills at the Elementary School level. Classroom action research with two cycles was used to investigate the impact of the method at Permata Bangsa Elementary school. The data was collected through observation on 17 students while doing activities and tests administered at the end of each cycle to obtain the result of the learning process. The data obtained were then compared, and the results show the influence on students' improvement in speaking. Thus, the implementation of ABL at the elementary school can significantly enhance students' oral competency.
\end{abstract}

Keywords: Elementary School, Speaking Skills, ABL

\section{Introduction}

Childhood is a golden period in which the learning process can take place effectively (Djamarah \& Aswan, 2013; Pinter, 2011). In responding to world challenges, the mastery of English for the next generation of the nation is necessary so that they can compete and excel in various fields in the international arena (Dupuy \& Krashen, 1993; Intarapanich, 2013). Therefore, the position of English as an international language is an important reason why this foreign language proficiency is very necessary to be invested early on. Studying foreign languages starting from an early age has several advantages, among which children can learn more efficiently and acquire more knowledge through interesting activities, especially those relating to the visual, color, role, music, and social activities of children in general (Fandiño \& Velandia, 2020). Secondly, the knowledge gained during childhood will be embedded in memory longer than the knowledge gained as we grow older. In addition, childhood is a period in which the "zone of proximal development" is growing very rapidly, so that learning that takes place at this stage will be more effective.

Although the current curriculum for English education for elementary school children in Indonesia is quite good, the education industry continues to try to develop it, considering the importance of early education (Juhana, 2014). Due to those changes, teachers who are acting as the final and direct source of education to children need to have constant training as well. There is no one-fit- all method in teaching English to young learners; teachers need to be introduced to different teaching methods. Having a large

$\begin{array}{lll}\text { History: } & & \text { Publisher: Undiksha Press } \\ \text { Received } & : \text { 28 February } 2020 & \text { Licensed: This work is licensed under } \\ \text { Revised } & : \text { 15 July } 2020 & \text { a Creative Commons Attribution 3.0 License } \\ \text { Accepted } & : \text { 26 July } 2020 & \text { CC (D) OP } \\ \text { Published } & : \text { : } 1 \text { August } 2020 & \end{array}$


range of teaching method knowledge will enable teachers to adapt their teaching, mostly when constant changes in curriculum are made (Gilakjani \& Ahmadi, 2011).

Along with the rapid development in today's learning technology, the problems that often arise are caused by: (1) A large number of students in one class or the large gap in English proficiency level among students. This often causes the teacher to have difficulty in organizing the learning process and ensuring that all students receive sufficient attention; (2) The problem of teachers' perceptions of their abilities as non-native English Speakers often leads teachers to be unsure of their own ability to help students achieve their expected abilities. In addition, the inferiority views of English teachers as non-native speakers make them unsure that there are many "local values" that can be applied in teaching English so that teachers and students have a more positive attitude toward their ability; (3) The objectives of English learning that are often associated with the test or test skills often overlook the critical side of English mastery as a global communication tool; (4) The facts encountered that many English teachers who are not qualified in English education.

English teacher of Permata Bangsa Elementary School, North Cikarang is a homeroom teacher who does not have English education qualifications or English literature. It results in a lack of knowledge of methods that can be applied in the classroom. This leads the students not to use English to communicate. It is not surprising that only $20 \%$ of the students can respond well when asked in English. Based on the problems faced by Permata Bangsa Elementary School teachers, this study aims to enhance students' speaking skills through the implementation of the "Activity- Based Learning" method. The following figure shows the reasons to apply the method. Dale (1969) points out that we tend to remember $90 \%$ of what we say and do, $70 \%$ of what we say, $50 \%$ of what we see and hear, $30 \%$ of what we see, $20 \%$ of what we hear and only $10 \%$ of what we read. In the Cone of Learning, it is further explained that knowledge and skill are grasped at its maximum level by doing dramatic presentations, simulating real experiences, and doing practical tasks. Therefore, Activity Based Learning suits to meet the learning target in terms of improving English speaking skill.

This study aims to identify whether the implementation of an activity- based learning (ABL) method can improve students' speaking skills at the Elementary School level.

\section{Materials and Methods}

Classroom action research (CAR) was used, and 17 students participated. CAR was conducted in cycles, and each cycle consists of four moments (phases) in the spiral of planning, action, observation, and reflection shown in Figure 1.

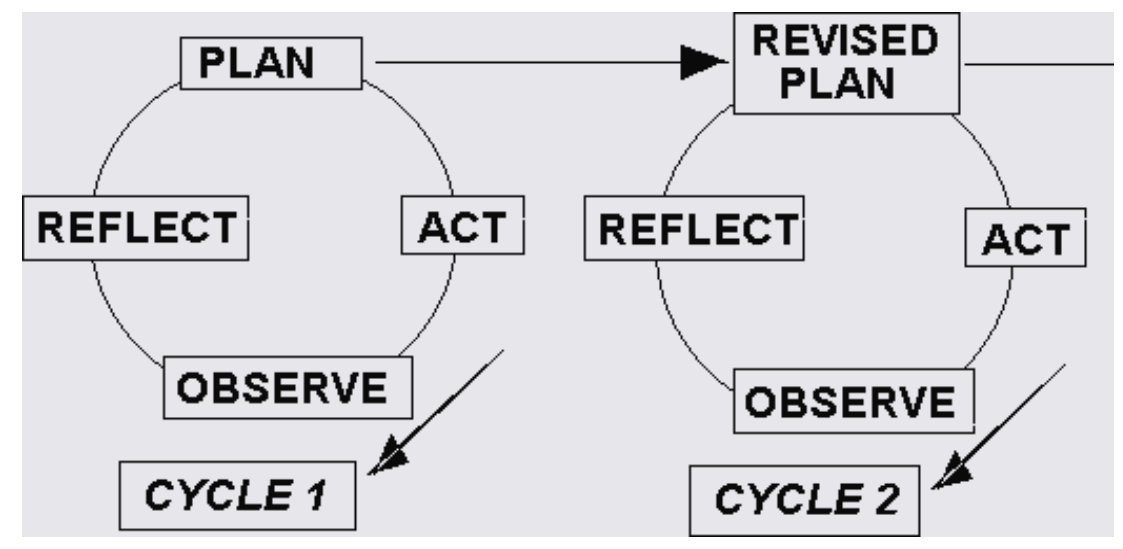

Figure 1. Research Cycles 
Activities in the learning process are usually chosen and arranged to meet the lesson objectives stated in the syllabus, and to identify whether the learning process or training is considered successful, criteria of successful teaching needs to established. According to Djamarah and Zain (2002), it is categorized into three levels. First, it is considered outstanding if the students are able to master the lesson completely. Second, it is weighed very well when most of the lessons $(76 \%-99 \%)$ are mastered by the students. Finally, when the students are able to understand $60 \%$ until $75 \%$ of the lesson. Meanwhile, the criteria for successful teaching established by the school is if students are able to understand $70 \%$ or more than $70 \%$ of the lesson.

The data was collected before the implementation of the ABL method to have a better understanding of the conventional teaching and learning practices at the school trough document observation and interview. The other data was gathered since the ABL method started to be implemented until it finished. At the beginning of the implementation, the pretest was administered to identify the level of their understanding. During the implementation, the observation was used to identify students' direct response. In the end, the post-test was administered to identify students' progress. Descriptive technique was used to analyze the data.

\section{Results and Discussion}

Prior to the cycles, preliminary research was conducted, and it shows that the teacher does not have a degree in English Education or English Literature, which results in a lack of teaching methods and English proficiency. Furthermore, she does not have a syllabus to teach. Besides, the focus of the learning process is students' ability to answer written questions for the exam. It is not surprising that only around $20 \%$ of the students can respond well when asked in English.

The first cycle was divided into two meetings. The first meeting was undergone on 23 August 2019. Singing a song related to the topic, racing (listen and respond physically and orally), doing role-play were the activities designed to meet the students' competency to be able to ask and give things. The second meeting of this cycle was conducted on August $30^{\text {th }}$ on the topic "preposition of place". At first, the students were asked to watch a video. After that, they were instructed to watch and copy what they have watched while saying out loud what they do. Those activities were designed to help students be able to give and ask for directions in English. A test was administered at the end of the second meeting.

The second cycle was delivered in 3 meetings on 6, 13, and 20 September 2019, respectively, with the course materials on topic "Hometown," "Happy Birthday," and "In the Classroom." Activities "Listening, touching and saying," watching a video related to the topic and doing role-play were the activities designed on the first meeting to help the students be able to ask and give information about their birthday using invitation expressions. The second meeting was designed to help students be able to ask and give permission through these activities, playing "listen and touch" game, watching a video, and doing role-play on giving and asking permission. The final meeting was designed to help the students be able to use superlative degree and to express agreement and disagreement through these sequences of activities: singing, creating a birthday calendar, and playing "superlative game." The final assessment of students' oral performance was administered at the end.

During the learning process of the first cycle, the researcher and observers identified that some students did not participate well in doing the activities because the lessons were all delivered in English. As a result, the use of Bahasa on the second cycle was needed for the part of the lesson that students found difficult to understand, and the result of this can be seen in Figure 2. 


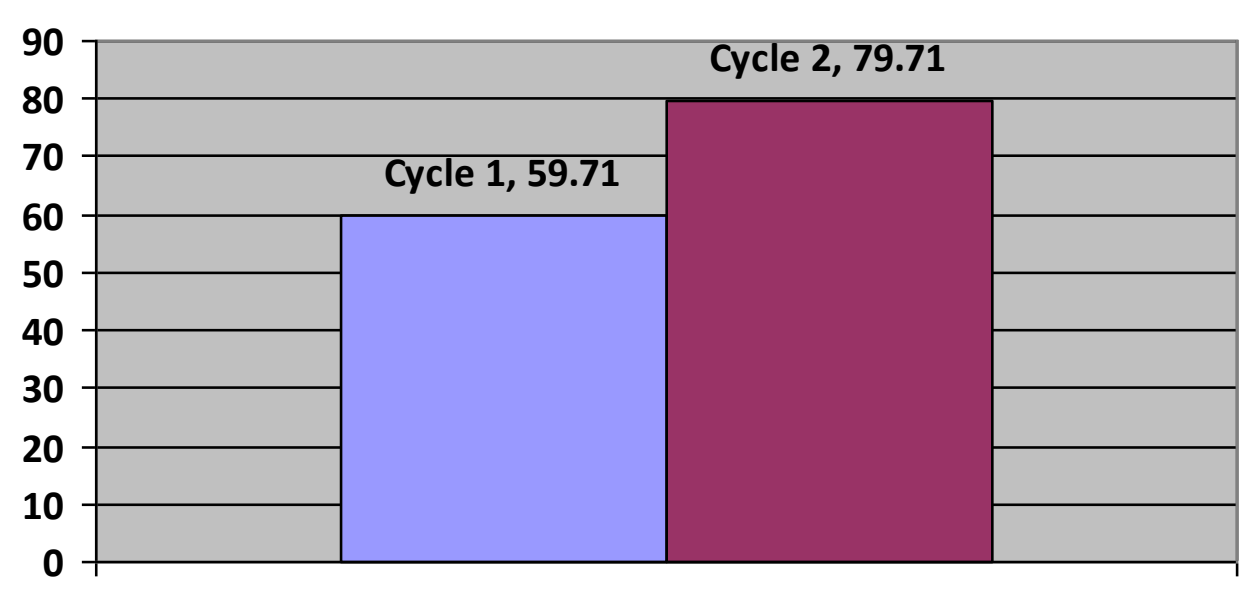

Students' Oral Perfomance

\section{Cycle $1 \square$ Cycle 2}

Figure 2. Research Results

The chart provides information that the average of students' oral performance on the first cycle is 59, 71, and it increases up to 20 points after the ABL implementation. The research results show that almost all students experience has an improvement in oral performance. The highest achievement in the first cycle was 90, and the lowest was 20. Meanwhile, in the second cycle, the lowest was 45 , and the highest was 100 . Only $5 \%$ of the students remains steady. In terms of minimum criteria of achievement (70) set by the school, almost $60 \%$ of the students did not meet the minimum criteria of achievement in the first cycle. However, it decreased dramatically to $18 \%$ after the second cycle due to the use of Bahasa for some parts such as difficult words they are not familiar with.

The other reason was they had got used to listening to instruction in English since the first cycle. Thus, the implementation of the activity-based learning method significantly improves students' oral performance. This is in line with what the school principal said." The English class with ABL method was fun, and the students were happy because they can understand it well". In addition, the findings are in accordance with Dale (2069) who points out that we tend to remember $90 \%$ of what we say and do, $70 \%$ of what we say, $50 \%$ of what we see and hear, $30 \%$ of what we see, $20 \%$ of what we hear and only $10 \%$ of what we read.

Activity-Based Learning (ABL) is a teaching method in which students learn at their own pace through and from teacher-facilitated activities (Gerngross \& Puchta, 1996). ABL started sometime during World War II. David Horsburgh is considered the pioneer of the ABL system. He opened a school called NEEL BAGH in Kolar. The school has a diverse Curriculum, which included music, carpentry, sewing, gardening, as well as school subjects. The teaching materials were systematically planned with different learning activities.

ABL method has created a visible improvement in children's learning and psychology (Akhalq et al., 2016). Children learn to make independent decisions at a young age, from choosing their activity card for the day, to marking their own attendance. Under the system, the curriculum is divided into small units, each a group of Self Learning Materials (SLM) comprising attractively designed study cards for English, Tamil, Maths, Science, and Social Science. When a child finishes a group of cards, he feels a sense of accomplishment of completing one 'milestone.' 
ABL can be one of the most effective methods to teach English to children because children can learn well when they are in their own familiar world (Moeed, 2019). The world of children is the world full of observing, trying, and making sense of all things around them. The nature of children's activities is playing, which involves physical activities, not only sitting calm, thinking, and memorizing a list of unfamiliar words or sentences (Sulianti, 2018). Only when children actively participate in the activity does learning happen at its maximum pace. In addition to that, children also need to learn on their own. In this case, they will initiate to participate, and the role of teachers is very crucial in making them interesting jump into the activity (Parinya S. Ngiamsunthorn, 2014).

There are several types of ABL, which are often used in teaching English both as a second and as a foreign language (Murcia, 2001). (1) Dramatization, it is defined as conversion into a dramatic form or reconstruction of an event, novel, story, etc. in a way suitable for a dramatic presentation; (2) Quiz, it is defined as a competitive activity in which participants should give the answers to the questions in a prescribed time following some pre-determined rules. (3) Group discussion is defined as discussing in smaller groups (four to fifteen students) about a given topic and reaching a decision or arriving at some conclusions; (4) Roleplay means Enacting some situations or playing the role of things, persons, characters, etc; (5) Educational Games. These are games that are designed to help students to learn about certain subjects, enhance concepts, understand different contents, learn a skill, etc. Brainstorming: It is a group activity in which group members are encouraged to produce a large number of ideas quickly on a theme or a problem without commenting on any one's viewpoints for subsequent discussion and evaluation; (6) Problem solving is a process of finding the solution to the problem by using one or more concepts or principles or formulae or required information.

\section{Conclusion}

This study aims to implement the activity-based activities (ABL) method to increase elementary school students' speaking skills. The results lead to the conclusion that ABL significantly improves students' performance in speaking. Students were previously passive in the learning process because they just listened to the teacher's explanation from the book. With ABL method, they have to move physically and orally respond based on the teacher's instruction.

\section{References}

Akhalq, M., Chishti, S. ul H., \& Iqbal, M. Z. (2016). Activity Based Teaching and Learning through Mentoring in Punjab Province of Pakistan: An Analysis. Mediterranean Journal of Social Sciences, 7(1). https://doi.org/10.5901/mjss.2016.v7n1s1p434

Djamarah, \& Aswan. (2013). Strategi Belajar Mengajar. Rineka Cipta.

Dupuy, B., \& Krashen, S. D. (1993). Incidental Vocabulary Acquisition in French as a Foreign Language. Applied Language Learning, 4(1), 55-63.

Escobar Fandiño, F. G., \& Silva Velandia, A. J. (2020). How an online tutor motivates Elearning English. Heliyon, 6(8). https://doi.org/10.1016/j.heliyon.2020.e04630

Gerngross, G., \& Puchta, H. (1996). Do and understand. Longman Harmer.

Gilakjani, A. P., \& Ahmadi, M. R. (2011). A Study of Factors Affecting EFL Learners ' English Listening Comprehension and the Strategies for Improvement. Journal of Language Teaching and Research, 2(5), 977-988. https://doi.org/10.4304/jltr.2.5.977988 
Intarapanich, C. (2013). Teaching Methods, Approaches and Strategies Found in EFL Classrooms : A Case Study in Lao PDR. Procedia - Social and Behavioral Sciences, 88, 306-311. https://doi.org/10.1016/j.sbspro.2013.08.510

Juhana. (2014). Teaching English to Young Learners : Some Points to be Considered. Asian Journal of Education and E-Learning (ISSN:, 2(1), 43-46.

Moeed, S. (2019). Activity-based Learning and Development of High Mental Abilities an Intention of Intermediate Level Chemistry Syllabus. International Journal of Theory and Application in Elementary and Secondary School Education (IJTAESE), 1(2), 131-144. https://doi.org/10.31098/ijtaese.v1i2.37

Murcia, M. (2001). Teaching English as A Second or Foreign Language : Third Edition. New Burry House Publisher.

Parinya S. Ngiamsunthorn. (2014). Effectiveness of teaching and learning mathematics for Thai university engineering students through a combination of activity and lecture based classroom. Asian International Journal of Social Sciences, 14(4), 104-116. https://doi.org/10.29139/aijss.20140406

Pinter, A. (2011). Children learning Second Languages. Palgrave MacMillan.

Sulianti, A. (2018). Peningkatan Kemampuan Pemahaman Dan Analisis Masalah Pada Psikologi Faal Melalui Pembelajaran Berbasis Aktivitas. Psympathic: Jurnal Ilmiah Psikologi, 5(2), 558-565. https://doi.org/10.15575/psy.v5i2.2152 